\title{
Consumer's behavior and rice attributes for Thai HomMali Rice in Sichuan Province of China
}

\author{
Isriya Nitithanprapas Bunyasiri \\ Prapinwadee Sirisupluxana
}

Department of Agricultural and Resource Economics

Faculty of Economics, Kasetsart University, Bangkok, Thailand

\section{Keywords}

China rice market, hedonic rice price, consumers' behaviors, market strategy

\begin{abstract}
Thailand has slowly regained its rice market share in China since 2014 after the abolishment of the rice pledging policy. With impressive economic growth, huge population and the Look West Policy of China created a great potential for a new market for Thai HomMali rice in Sichuan Province where there were 81 million people with 8-9 percent of economic growth during 2014-15. Chengdu, the capital, experienced an increase in GDP per capita 9-10 percent, and the food expenditure per capita grew at 8 percent. To facilitate a better understanding for this new market, consumers' preference for Thai HomMali rice is needed and the implicit price of the important attribute of HomMali rice should be investigated. This study employed consumer survey of 412 samples in Chengdu and used the hedonic price model to analyze the implicit price of each attribute for HomMali Rice. The results show that modern trade, supermarket, and convenient store are the main marketplaces to purchase rice of Chengdu consumers. The softness and taste of Thai HomMali are the major factors that consumers preferred. Those consumers buying Thai rice have comparatively higher income and education, and have more cheerful lifestyle. The empirical results of consumer preference reflected that significant attributes influencing price are color, the percentage of broken rice, new-season crop rice, rice standard, rice brand, softness, taste and fragrance. The implicit price of Thai rice depends more on cooking and eating quality. As a result, to make Sichuan province become a potential high-quality Thai rice market, Thai government and traders should create product differentiation by emphasizing on Thai rice quality and standard in terms of physical quality, cooking and eating quality according to the Chinese demand.
\end{abstract}

Corresponding author: Isriya Nitithanprapas Bunyasiri

Email addresses for corresponding author: fecoiyb@ku.ac.th

First submission received: 15th April 2017

Revised submission received: 21st August 2017

Accepted: 15th September 2017

\section{Introduction}

China is the number one importing country in the global rice market. Its rice import increased from 2.9 million tons in 2001/02 to 4.5 million tons in 2014/15(USDA, 2014). Rice import to China is controlled by the central government under the import quota system at 5.22 million tons per annum in which $50 \%$ is for short grain rice imports while the rest is for long grain rice. China started importing long grain rice in 2002 with total quantity imports of 216,214 tons. During 2006- 2010, Thailand market share was the highest. On average, more than $90 \%$ of the long grain rice imports of China is from Thailand. However, the Thai market share of long grain rice decreased drastically to an average of $9 \%$ of total long grain rice import during 2012-2013 due mainly to the rice pledging program that raised the Thai rice price higher than the world price. As a result, Thailand lost its price competitiveness to other major rice exporting countries, especially Vietnam and Pakistan, and most of the Thai market shares are taken by those countries.

Nevertheless, the abolishment of the rice pledging program in 2014 led to the decrease in Thai rice import price in China which closed the rice price gap between Thai and Vietnam. Eventually, Thai rice gradually regained some of its market share, approximately to 37 percent in 2015.

With the existing large population and high economic growth rate, China has a high economic 
potential in importing rice with strong demand for HomMali rice from Thailand. However, the preferences for rice consumption in China vary across regions. For example, the Chinese living in the Northern part of the Yangtze River prefer consuming short grain rice, while those living in the Southern part prefer consuming long grain rice. Guangdong province (Guangzhou city and Shenzhen city) is the major market for Thai HomMalirice; nevertheless, this market is facing with high tendency of price competition from the Vietnamese rice.

Provinces in the Western region of China, especially Sichuan Province, have a great potential for market expansion for HomMali rice. This due mainly to the "Look West Policy of China" that generated high economic growth to Sichuan Province which was more than 10\% growth during 2010-2013, and between 8-9\% during 2013-2014.

In addition, Sichuan Province is one of the most populated province in which 81 million people are registered. Chengdu, the capital of Sichuan, experienced the GDP growth of 9-10\% during 2013-2014 with a sharp increase of GDP per capita of $9 \%$ growth rate. These increases enable people to enjoy better standard of living and changes of consumption behavior, especially the increase of food expenditure that increased by $8 \%$ and consuming more variety of quality food items. Particularly, those consumers under 35-year-old are spenders of high quality products. In addition, tourism to Thailand has become increasingly popular for people in Chengdu, and once these tourists experienced with fragrant and aroma taste of HomMali rice create a demand for more imports of HomMali from Thailand (information obtained from an interview with staffs of Thai Consulate in Chengdu during March 2014).

The acceptance of HomMali rice, the sharp increase of per capita income, and changing consumer food expenditure of young people in Chengdu are evidences of potential market expansion of Thai rice market in Sichuan province. Therefore, to have a better understanding and formulation of consumer behavior on Thai rice that enables an appropriate formulation of strategy marketing plan for this new market in Sichuan province of China, the study on Chinese consumer behavior of Thai Hom Mali rice and the importance Thai rice attributes are needed. The analytical of this paper only focuses on Chengdu consumers.

\section{The concept and model of Hedonic Price}

Theoretically, willingness to pay can be quantified either through revealed preference valuation or stated preference valuation. The revealed preference is obtained from experiment or market retail price responses, real purchase data, to cover the range of consumer preferences due to price variation. The stated preferences can be taken from direct surveys of the designed studies by asking the consumers about their willingness to pay for a particular product or by indirect surveys using ranking or sorting of product characteristics by applying conjoint analysis and discrete choice analysis (Breidert, 2006).

The hedonic price analysis is based on the revealed preference approach that uses real purchase data which has been incorporated information about their characteristics into the product price. It can identify customer-relevant characteristics to express consumer's preferences. In addition, it has been applied to identify characteristics of a product which significantly influence the price. The first contribution to the hedonic price method was done by Waugh (1929) to estimate the relationship between the prices of fresh asparagus and the quality (physical characteristics) of that vegetable. Although there were other studies, the major contributions of hedonic method come from the theoretical works towards New Consumer Theory of Lancaster (1966) and the work of Rosen (1974).

Unnevehr (1986) used implicit prices of grain characteristics in terms of physical characteristics (milling quality), chemical characteristics (cooking quality), and Gelatinization temperature (Alkali spread) to identify cooking time and aroma to evaluate the rice breeding in Thailand, Indonesia, and the Philippines. The physical characteristics include color, rate of breakage, shape of grain, percentage of chalky grain and purity. The chemical characteristics (cooking quality) include percentage of amylose content and gel consistency to measure softness of rice. Unnevehr's study found that demand for grain shape and some chemical characteristics, such as per cent of amylose, varies across these three countries. Kaosa-ard and Juliano (1991) and Kawamura (1999) have used a hedonic price model to study the relationship between physical characteristics of rice such as the length of rice, broken rice, purity and the decision to buy rice and found that physical properties have an influence on consumer decisions to 
purchase rice. Dalton (2004) conducted a study using hedonic price model to find the economic value of the rice attributes for upland rice and found that rice varieties were significantly correlated with the characteristics of the rice milling, which is consistent with the study of Adesina and Baidu-Forson (1995) and Untong and Kaosa-ard (2010), analyzed relationship between price and quality of rice in modern trade market in China using hedonic price model involved with 102 samples obtained from survey of packaged rice in modern trade markets in Shenzhen and Guangzhou. The results revealed that factors had positive impacts on price of rice were the fragrant of HomMali followed by quality of package and rice brand. However, the certification logo of Thai HomMali rice standard was not included in the model and reflected that Chinese consumers do not concern about the certification logo in the short period of marketing. While the study of Sirisupluxana and Bunyasiri (2014) found that Thai rice consumers give a priority to physical quality such as purity and percent of broken rice than cooking quality such as fragrance and softness. From the empirical results, the main idea of hedonic price theory is based on the quality or the attributes of the products and the consumer preference derived from product characteristics not the product itself.

A typical hedonic price function was employed to analyze the quality or characteristics of the product on product price. It can be indicated as $P_{i}=f\left(z_{i 1}, z_{i 2}, \ldots, z_{i m}\right)$ where $P_{i}$ is the price of one unit of $\mathrm{i}^{\text {th }}$ product and $z_{i j}$ is the $\mathrm{j}^{\text {th }}$ characteristic $(j=1,2, \ldots, m)$ for one unit of $\mathrm{i}^{\text {th }}$ product contained. The implicit price or the shadow price of a characteristic (hedonic price) can be obtained from the partial derivative of the price function with respect to a particular characteristic as $\frac{\partial p_{i}}{\partial z_{i j}}=\frac{\partial f\left(z_{i 1}, z_{i \alpha} z_{m,}, z_{i m}\right)}{\partial z_{i j}}=p_{j}\left(z_{i 1}, z_{i 2}, \ldots, z_{i m}\right)$ which indicated that if the amount of particular $\mathrm{j}^{\text {th }}$ characteristic changes, the price of $i^{\text {th }}$ product will also change holding other characteristics constant. Thus, the market price of a product is the sum of all the implicit prices of the quality characteristics (Rosen, 1974).

Generally, the functional form of the hedonic price cannot be derived from the economic theory, empirically the most frequently functional forms used in the hedonic regression such as linear, log-log, or semi-log. The simplest one is a linear form given by (Unnevehr, 1986 and Ladd and Suvannuant, p. 505, 1976)

$$
P_{i}=\alpha_{0}+\sum_{j=1}^{m} \alpha_{i j} z_{i j}+\varepsilon
$$

Where $\mathrm{P}_{\mathrm{i}}$ is the price of particular $\mathrm{i}^{\text {th }}$ product and $\varepsilon$ is the error term, $\mathrm{z}_{\mathrm{ij}}$ is the independent variable of the $\mathrm{j}^{\text {th }}$ attribute of $\mathrm{i}^{\text {th }}$ product and $\alpha_{i j}$ are unknown parameters needed to be estimated

$$
\frac{\partial \mathrm{P}_{\mathrm{i}}}{\partial \mathrm{z}_{\mathrm{ij}}}=\alpha_{i j}
$$

The regression coefficient $\alpha_{i j}$ for $j=1,2, m$ is the marginal change in product price with respect to a change of a particular $j^{\text {th }}$ characteristic or the implicit values of each attribute of $i^{\text {th }}$ product.

The implicit values are used for estimating the consumer surplus obtained from the attribute of a product that related to the better quality. As a particular product attribute changes, the quantity of the product will change, causing the product demand curve shifted to the right, from demand curve DD to $\mathrm{D}^{*} \mathrm{D}^{*}$ (Figure 1), holding the price of the particular product and all other attributes of the product are given constant. The increase of quantity demanded for consumption is reflected by the increase of consumer utility obtained from each unit of product consumed. The gain of consumer surplus from the quantity of product consumed is represented by the following equation.

$$
G=\sum_{\mathrm{j}=1}^{\mathrm{m}}\left(\mathrm{z}_{\mathrm{ij}}^{*}-z_{i j}\right) * \alpha_{i j}
$$

Where $G$ is the gained consumer surplus obtained from additional consumed of product unit. $\alpha_{i j}$ is the implicit price of the $j^{\text {th }}$ attribute (which derived from equation (2). $z_{i j}^{*}$ and $z_{i j}$ are the new value and original value of the $j^{\text {th }}$ attribute obtained from one unit of $\mathrm{i}^{\text {th }}$ product consumed given the implicit price of the $j^{\text {th }}$ attribute and the consumer surplus is represented by the shaded area in figure 1 and it can be estimated by equation (4) as follow

$$
C S=q_{R} G+\frac{1}{2}\left(q_{R}^{*}-q_{R}\right) G
$$


Where $C S$ is the total consumer surplus. $q_{R}^{*}$ is the quantity of the product which reflects changes in attribute of the product consumed by consumer.

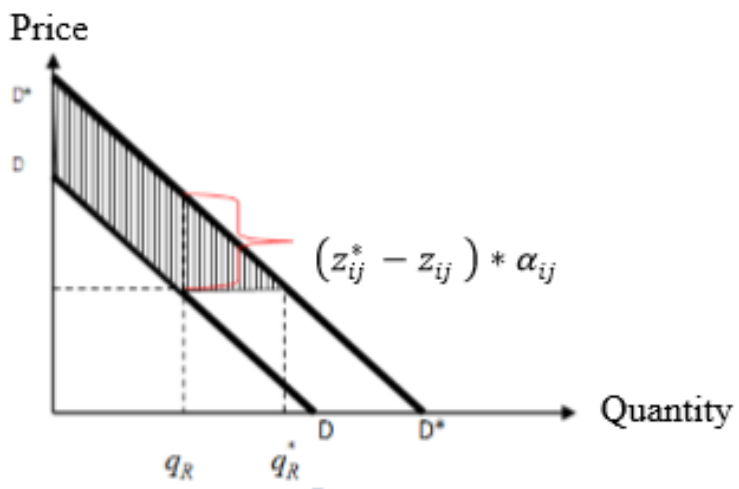

Figure 1 Consumer surplus after quality improvement

\section{Research methodology}

The research focuses on the rice consumer behavior in Chengdu using purposive sampling by interviewing respondents who are willing to participate in the research. The criteria for sample selection is based on the distribution of rice consumers with different age groups and are scattering around the rice retailing stores such as modern trade (Carrefour), supermarkets in the department stores (Ito, Isetan) and convenient store (Hongqi). The primary data was collected through field survey by using structured questionnaire targeted for a total 400 samples. However, the actual collected samples are 412 samples.

Both qualitative and quantitative approaches are employed in this research. In order to analyze the relationship among factors affecting rice consumption of consumer in Chengdu, the statistical testing of Chi- square, T-test and F-test are employed. The Hedonic price model is constructed for analyzing the relationship between rice quality attributes, particularly physical, cooking and eating quality and the price of rice. The Likert scale from 1 through 5 has been used to identify the importance of physical, eating and cooking characteristics that consumers in Chengdu preferred. Attributes and their expected effect on price of HomMalirice has been listed in Table 1 and will be utilized in the hedonic model.

\begin{tabular}{|c|c|c|}
\hline Attributes & Unit classification & $\begin{array}{c}\text { Expected } \\
\text { effect }\end{array}$ \\
\hline \multicolumn{3}{|l|}{ Physical quality } \\
\hline Length of rice kernels & Shape of grain 1-5 (1 = shortest 5 = longest $)$ & + \\
\hline Color (whiteness) & $\begin{array}{l}\text { Importance of whiteness of rice } 1-5(1=\text { least } \\
\text { importance } 5=\text { most importance })\end{array}$ & + \\
\hline Percentage of broken rice & $\%$ of broken rice: $1-5$ (1=lowest $5=$ highest $)$ & - \\
\hline Rice standard & $\begin{array}{l}\text { Importance of whiteness of rice } 1-5(1=\text { least } \\
\text { importance } 5=\text { most importance) }\end{array}$ & + \\
\hline New crop rice & 1-5 (oldest to newest) & + \\
\hline Brand image & $\begin{array}{l}\text { Importance of brand image }(1=\text { least } \\
\text { importance } 5=\text { most importance })\end{array}$ & + \\
\hline \multicolumn{3}{|l|}{ Cooking quality } \\
\hline Softness after cooking & $\begin{array}{l}\text { Importance of softness after cooking }(1=\text { least } \\
\text { importance } 5=\text { most importance })\end{array}$ & + \\
\hline \multicolumn{3}{|l|}{ Eating quality } \\
\hline Rice taste & $\begin{array}{l}\text { Importance of rice taste }(1=\text { least importance } 5 \\
=\text { most importance) }\end{array}$ & + \\
\hline Fragrance of rice after cooking & $\begin{array}{l}\text { Importance of fragrance after cooking }(1= \\
\text { least importance } 5=\text { most importance })\end{array}$ & + \\
\hline
\end{tabular}

Table 1 Selected attributes of hedonic price analysis and expected relationship between price and the attributes 


\section{Research results and discussions}

The research results are indicated that most respondents are female (60.85 percent of the total sample) as they are likely to be the decision makers of household food purchasing with the average age of 29-year-old. The majority of the respondents are concerned as economic active labor forces and the potential future Thai rice purchasers (54\%for 26-55-year-old). Most of the respondents had bachelor degree and higher (49\% of the total sample) and the majorities are employers (41\%). The average monthly income of the respondents is 5,459 RMB/month, and the highest income is more than $10,000 \mathrm{RMB} / \mathrm{month}$.

\section{Chengdu consumer preference}

Majority of the people in Chengdu purchased packaged rice (66.4\% of the total respondents) and only 8 percent purchased un-packaged rice. In addition, those in the age group 26-35-year-old buy packaged rice more than all other age groups (Table 2).

\begin{tabular}{lcccc}
\hline \multicolumn{1}{c}{ Type of package } & $<\mathbf{2 5}$ year-old & $\mathbf{2 6 - 3 5}$ & $\mathbf{3 6 - 5 5}$ & year-old \\
year-old & 55 Year-old \\
\hline Packaged rice & 88 & 108 & 33 & 5 \\
Un-packaged rice & $(59.1)$ & $(74.5)$ & $(67.3)$ & $(50.0)$ \\
Both packaged and un-packaged rice & 21 & 7 & 2 & 2 \\
& $(14.1)$ & $(4.8)$ & $(4.1)$ & $(20.0)$ \\
& 40 & 30 & 88 & 3 \\
& $(26.8)$ & $(20.7)$ & $(24.4)$ & $(30.0)$ \\
\hline
\end{tabular}

Remark: There is a statistical significant relationship between type of package and age group at $95 \%$ confidence level (CI).

Table 2 Frequency and percentage of sample purchased packaged rice and un-Packaged rice

Most of the consumers, $57.4 \%$ of the total respondents, purchased rice at the modern trade (Carrefour and Isetan) followed by the supermarket or convenient stores. Only few purchased rice at the wholesale market (7.7 percent). Considering the age group of rice buyers, the supermarket and convenient stores are the places where the young people with age of less than 25-year-old bought their rice (Table 3).

\begin{tabular}{lccccc}
\hline \multicolumn{1}{c}{ Location of purchase } & Total & $\begin{array}{c}<25 \text { year- } \\
\text { old }\end{array}$ & $\begin{array}{c}\mathbf{2 6 - 3 5} \text { year- } \\
\text { old }\end{array}$ & $\begin{array}{c}\mathbf{3 6 - 5 5} \text { year- } \\
\text { old }\end{array}$ & $\begin{array}{c}>\text { 55 year- } \\
\text { old }\end{array}$ \\
\hline Modern trade & 225 & 80 & 99 & 33 & 7 \\
Supermarket/convenient & $(57.4)$ & $(49.1)$ & $(63.5)$ & $(60.0)$ & $(53.8)$ \\
Store & 222 & 101 & 78 & 31 & 8 \\
Wholesale market & $(56.2)$ & $(62.0)$ & $(50.0)$ & $(56.4)$ & $(61.5)$ \\
& 30 & 16 & 6 & 5 & 3 \\
& $(7.7)$ & $(9.9)$ & $(3.9)$ & $(9.1)$ & $(23.1)$ \\
\hline
\end{tabular}

Remark: There is a statistical significant relationship between modern trade and age group at $95 \%$ confidence level. The relationship between supermarket and convenient store is also found statistical significant at $90 \%$ confidence level. Respondents can answer more than 1 question

Table 3 Frequency and percentage of household rice purchasing classified by purchasing location and age groups

Mostly consumers in Chengdu purchased only Chinese rice. Majority of consumers purchased rice produced in the north-eastern province called "Tongbei rice". The second category purchased both Chinese rice and Thai rice, while only few purchased only Thai rice (Table 4). However, the type of rice purchased has no statistically significant relationship with the age group of consumers (Chi-square test equals 7.6, and P-value equal to 0.49). 


\begin{tabular}{ccccccc}
\hline & \multicolumn{3}{c}{ Number of respondents } & \multicolumn{3}{c}{ Percentage } \\
\cline { 2 - 7 } Age group & $\begin{array}{c}\text { Buying } \\
\text { Chinese } \\
\text { rice only }\end{array}$ & $\begin{array}{c}\text { Buying } \\
\text { Thai rice } \\
\text { only }\end{array}$ & $\begin{array}{c}\text { Buying } \\
\text { both }\end{array}$ & $\begin{array}{c}\text { Buying } \\
\text { Chinese } \\
\text { rice only }\end{array}$ & $\begin{array}{c}\text { Buying } \\
\text { Thai rice } \\
\text { only }\end{array}$ & $\begin{array}{c}\text { Buying } \\
\text { both }\end{array}$ \\
\hline Total & 237 & 10 & 104 & 67.5 & 2.8 & 29.6 \\
< 25 year-old & 92 & 3 & 41 & 67.6 & 2.2 & 30.1 \\
26-35 year-old & 104 & 3 & 33 & 74.3 & 2.1 & 23.6 \\
36-55 year-old & 31 & 2 & 21 & 57.4 & 3.7 & 38.9 \\
$>$ 55 year-old & 6 & 1 & 6 & 46.2 & 7.7 & 46.2 \\
\hline
\end{tabular}

Table 4 Frequency and percentage of samples buying Chinese rice,

Thai rice and both Chinese rice and Thai rice

Consumers who purchased only Thai rice had comparatively higher income and education. The average monthly income for the respondents indicated for purchasing only Thai rice is 17,000 RMB which is higher than those purchased only Chinese rice (5,371 RMB). It was found that there is a statistically significant relationship between household income and the type of rice purchased at the confidence level of $95 \%$. In addition, respondents who purchased only Thai rice had an average year of education of 16 years which is higher than those purchased both Chinese rice and Thai rice (13.8 years). Furthermore, there is a statistically significant relationship between years of education of the household head and type of rice purchased at confidence level of $99 \%$.

There are two popular types of Chinese rice, rice produced in Sichuan province and Tongbei rice. On the average consumers in Chengdu purchase Chinese rice two times a month, around 5-10 kg per each time with an average price of $6.1 \mathrm{RMB} / \mathrm{kg}$ and the most popular size of packaged rice is in the range of 5$10 \mathrm{~kg}$. For those who purchase Thai rice, the amount of purchase is averaged at one time a month, around $5-10 \mathrm{~kg}$ with the average price of $11.3 \mathrm{RMB} / \mathrm{kg}$. The popular size of packaged Thai rice is $5 \mathrm{~kg}$. It is clear that those respondents purchase Thai rice paid a comparatively higher price and higher rice consumption expenditure than those purchased only Chinese rice (Table 5).

\begin{tabular}{|c|c|c|c|c|c|c|}
\hline \multirow[b]{2}{*}{ Statistics } & \multicolumn{3}{|c|}{ Chinese rice } & \multicolumn{3}{|c|}{ Thai rice } \\
\hline & $\begin{array}{c}\text { Quantity } \\
\text { purchased } \\
\text { per month } \\
\text { (Kg.) }\end{array}$ & $\begin{array}{c}\text { Price per } \\
\text { Kg. } \\
\text { (RMB) }\end{array}$ & $\begin{array}{l}\text { Expenditure } \\
\text { per month } \\
\text { (RMB) }\end{array}$ & $\begin{array}{c}\text { Quantity } \\
\text { purchased } \\
\text { per month } \\
\text { (Kg.) }\end{array}$ & $\begin{array}{l}\text { Price per Kg. } \\
\text { (RMB) }\end{array}$ & $\begin{array}{c}\text { Expenditure } \\
\text { per month } \\
\text { (RMB) }\end{array}$ \\
\hline Average & 19.4 & 6.1 & 66 & 14.1 & 11.3 & 74.7 \\
\hline Minimum & 1 & 1 & 5 & 1 & 1 & 3 \\
\hline Maximum & 200 & 20 & 1,000 & 150 & 40 & 400 \\
\hline Std. Dev. & 27.4 & 3.2 & 98 & 25.7 & 6.2 & 69.4 \\
\hline
\end{tabular}

Table 5 Descriptive statistics of average monthly expenditure on

Chinese rice and Thai rice purchasing

The most important factor that most consumers in Chengdu considered when purchasing Thai rice is the quality of Thai rice, especially the fragrance and the softness, followed by hygiene, brand, and price. All these factors are not different among age group of the respondents and types of rice consumers (Table $6-7)$.

\begin{tabular}{lcccccccc}
\hline \multirow{2}{*}{ Factors } & \multicolumn{2}{c}{$\mathbf{2 0 - 2 5}$ year-old } & \multicolumn{2}{c}{$\mathbf{2 6 - 3 5}$ year-old } & \multicolumn{2}{c}{ 36-55 year-old } & \multicolumn{2}{c}{$>$ 55 year-old } \\
\cline { 2 - 9 } & Number & $\%$ & Number & $\%$ & Number & $\%$ & Number & $\%$ \\
\hline Price & 43 & 25.9 & 34 & 21.5 & 14 & 25.5 & 5 & 38.5 \\
Hygiene & 60 & 36.1 & 62 & 39.2 & 23 & 41.8 & 9 & 69.2 \\
Quality(1) & 137 & 82.5 & 130 & 82.3 & 45 & 81.8 & 11 & 84.6 \\
Brand & 38 & 22.9 & 40 & 25.3 & 14 & 25.5 & 5 & 38.5 \\
\hline
\end{tabular}

Remarks: (1) Softness and fragrance of rice.

Table 6 Frequency and percentage of most important factors in

purchasing rice classified by age groups 


\begin{tabular}{|c|c|c|c|c|c|c|}
\hline \multirow[t]{2}{*}{ Factors $(1)$} & \multicolumn{2}{|c|}{ Total sample } & \multicolumn{2}{|c|}{$\begin{array}{l}\text { Buying Chinese rice } \\
\text { only }\end{array}$} & \multicolumn{2}{|c|}{ Purchased Thai rice ${ }^{(2)}$} \\
\hline & Number & Percentage & Number & Percentage & Number & Percentage \\
\hline Price & 97 & 24.3 & 57 & 24.4 & 29 & 25.4 \\
\hline Hygiene & 159 & 39.8 & 93 & 39.7 & 47 & 41.2 \\
\hline Quality(3) & 327 & 81.8 & 197 & 84.2 & 92 & 80.7 \\
\hline Brand & 97 & 24.3 & 93 & 39.7 & 31 & 27.2 \\
\hline
\end{tabular}

Remarks: (1) Respondent can answer more than one question; (2) Either purchased Thai rice only or purchased both Thai rice and Chinese rice; and (3) Softness and fragrance of rice.

Table 7 Frequency and percentage of important factors in deciding of rice buying classified by rice-type purchased group

The important physical characteristics that consumer in Chengdu considered when purchased rice are the cleanness (extremely important), followed by rice standard (extremely important), logo of safety/hygiene certification (very important), new crop rice (very important) and color of rice kernels (very important). The most important factor that consumers who buy only Thai rice concerned is information about special properties of Thai rice characteristic (extremely important), followed by cleanness (extremely important), new crop rice, the location of packing, logo of safety/hygiene certification and rice standard, respectively. However, the location of packing revealed that the score for packaged locally and packaged abroad are equal and indicated a very important factor (Table 8). This reflected that rice consumers in Chengdu are mostly unaware of the difference of packing location which is indicated by the barcode on the package. The barcode starting with number 69 indicated packaged locally, while starting with number 885 means packaged abroad. Furthermore, consumers who buy Thai rice only prefer new crop rice compared to those who buy only Chinese rice and concern more about type of packaging (there is a statistically significant difference among group of buying).

Considering, the difference among the three groups of purchasing rice (buying Chinese rice only, buying Thai rice only, and buying both Chinese rice and Thai rice), it was found that factors such as new crop rice, color of rice kernels (whiteness), type of packing, rice standard, detail of cooking method, history of rice/production process, and special property of rice information were statistically significant difference among these three groups. It is interesting to note that respondents buying Thai rice only give more weight on the importance of attributes on new crop rice, length of rice kernels, type of packaging, detail of cooking method, history of rice/production process, and special rice characteristic information more than those respondents who buy only Chinese rice (Table 8).

\begin{tabular}{|c|c|c|c|c|c|}
\hline Physical characteristics & $\begin{array}{c}\text { Total } \\
\text { sample }\end{array}$ & $\begin{array}{l}\text { Buying } \\
\text { Chinese } \\
\text { rice only }\end{array}$ & $\begin{array}{l}\text { Buying } \\
\text { Thai rice } \\
\text { only }\end{array}$ & $\begin{array}{c}\text { Buying } \\
\text { both }\end{array}$ & F-Stat \\
\hline Packed locally & 3.36 & 3.41 & 4.00 & 3.19 & 0.729 \\
\hline Packed abroad & 3.40 & 3.38 & 4.00 & 3.39 & 0.838 \\
\hline New crop rice* & 4.05 & 4.08 & 4.10 & 3.97 & 2.388 \\
\hline Old crop rice & 3.18 & 3.28 & 3.00 & 2.97 & 0.920 \\
\hline Percentage of broken rice & 3.66 & 3.72 & 3.10 & 3.57 & 0.650 \\
\hline Length of rice kernels & 3.41 & 3.35 & 3.50 & 3.52 & 1.407 \\
\hline Color of rice kernels & 3.89 & 3.95 & 3.86 & 3.78 & 4.723 \\
\hline Cleanness & 4.51 & 4.56 & 4.29 & 4.41 & 0.413 \\
\hline Type of packaging** (vacuumed or not) & 3.62 & 3.64 & 3.80 & 3.55 & 3.603 \\
\hline Rice Standard & 4.24 & 4.39 & 3.89 & 3.94 & 6.760 \\
\hline Logo of safety/hygiene certification & 4.05 & 4.13 & 3.90 & 3.87 & 1.976 \\
\hline Detail of cooking method * & 3.35 & 3.37 & 3.40 & 3.30 & 2.561 \\
\hline History of rice/production process pre $^{* *}$ & 3.52 & 3.61 & 3.90 & 3.29 & 3.603 \\
\hline Special rice characteristic information ${ }^{* * * *}$ & 3.57 & 3.52 & 4.33 & 3.31 & 5.853 \\
\hline Brand image of the rice & 3.56 & 3.65 & 3.60 & 3.36 & 0.758 \\
\hline \multicolumn{6}{|c|}{$\begin{array}{l}\text { Remarks: Score } 1-1.8=\text { unimportant; } 1.81-2.6=\text { somewhat important; } 2.61-3.4=q u i t e \text { important } 3.41-4.2 \\
\text { very important; and } 4.21-5.0=\text { extremely important. Where: }{ }^{*}=\text { significant at } 90 \% \mathrm{CI} ; * *=\text { significant at } \\
95 \% \mathrm{CI} \text {; and } * * *=\text { significant at } 99 \% \mathrm{CI}\end{array}$} \\
\hline
\end{tabular}

Table 8 Average score of physical characteristics that consumers emphasized in rice purchasing classified by rice-type purchased group 
The physical factors that consumers in Chengdu placed important in purchasing rice are different among age groups such as factors on percentage of broken rice and type of packaging. Noticeably, the higher the age group gives higher weight on the importance of the percentage of broken rice, followed by the younger age group (those between 36 and 55-year-old places importance level at score of 3.82, 26-35year-old places importance level at score of 3.68) and less than 26-year-old places importance level at score of 3.47, respectively. The similar raking was also found in the type of packing (Table 9)

\begin{tabular}{|c|c|c|c|c|c|}
\hline Physical characteristics & $\begin{array}{c}<26 \\
\text { year-old }\end{array}$ & $\begin{array}{c}26-35 \\
\text { year-old }\end{array}$ & $\begin{array}{c}36-55 \\
\text { year-old }\end{array}$ & $\begin{array}{c}>55 \\
\text { year-old }\end{array}$ & F-test \\
\hline Packed locally & 3.31 & 3.28 & 3.38 & 3.64 & 0.584 \\
\hline Packed abroad & 3.27 & 3.39 & 3.43 & 3.67 & 1.380 \\
\hline New crop rice & 3.92 & 4.05 & 4.25 & 3.67 & 1.202 \\
\hline Old crop rice & 3.03 & 3.27 & 3.42 & 2.83 & 1.596 \\
\hline Percentage of broken rice ${ }^{*}$ & 3.47 & 3.68 & 3.82 & 3.25 & 2.122 \\
\hline Length of rice kernels & 3.33 & 3.31 & 3.52 & 3.75 & 0.594 \\
\hline Color of rice kernels & 3.8 & 3.81 & 4.00 & 4.27 & 0.910 \\
\hline Cleanness & 4.58 & 4.47 & 4.36 & 4.80 & 1.054 \\
\hline Size of packed rice $(5 \mathrm{Kg}$ ) & 3.37 & 3.16 & 3.62 & 3.38 & 1.576 \\
\hline Type of packaging ${ }^{* * *}$ & 3.51 & 3.65 & 3.91 & 3.64 & 5.227 \\
\hline Rice Standard & 4.24 & 4.28 & 4.20 & 3.75 & 0.789 \\
\hline Logo of safety/hygiene certification & 4.09 & 4.11 & 3.89 & 3.92 & 0.432 \\
\hline Detail of cooking method & 3.36 & 3.41 & 3.31 & 3.08 & 0.187 \\
\hline History of rice/production process ${ }^{* *}$ & 3.57 & 3.59 & 3.43 & 3.17 & 0.801 \\
\hline Nutrition information & 3.76 & 3.74 & 3.6 & 3.42 & 0.353 \\
\hline Special rice characteristic information & 3.55 & 3.67 & 3.35 & 3.33 & 1.013 \\
\hline Brand image of the rice & 3.34 & 3.37 & 3.42 & 2.78 & 0.674 \\
\hline
\end{tabular}

Remarks: Score 1-1.8=unimportant; 1.81-2.6=somewhat important; $26.1-3.4=q u i t e$ important 3.414.2 very important; and $4.21-5.0=$ extremely important. Where: ${ }^{*}=$ significant at $90 \% \mathrm{CI}$; ${ }^{* *}=$ significant at $95 \% \mathrm{CI} ;{ }^{* * *}=$ significant at $99 \% \mathrm{CI}$

Table 9 Average score of physical factors that consumer placed important in rice purchasing classified by age-group

The most important characteristic of rice cooking and eating quality considered by Chengdu rice consumers are taste of rice, followed by softness after cooking, and the fragrance, respectively. The ranking of these characteristics are the same among the respondent groups; however, those consumers who purchased Thai rice only concern more on taste and fragrance respectively. In addition, the same pattern of ranking is also found with statistically insignificant among respondents classified by age groups (Table 10 to 11). These results consistent with the study of Musa et al. (2011) indicated that cooking quality such as flavor and taste of cooking affects consumers purchasing behavior for rice in Malaysia.

\begin{tabular}{lccccc}
\hline Cooking and eating quality & $\begin{array}{c}\text { Total } \\
\text { sample }\end{array}$ & $\begin{array}{c}\text { Buying } \\
\text { Chinese } \\
\text { rice only }\end{array}$ & $\begin{array}{c}\text { Buying } \\
\text { Thai rice } \\
\text { only }\end{array}$ & $\begin{array}{c}\text { Buying } \\
\text { both }\end{array}$ & F-Test \\
\hline Taste & 4.30 & 4.43 & 4.50 & 4.34 & 0.217 \\
Fragrance & 4.13 & 4.14 & 4.20 & 4.11 & 0.066 \\
Softness after cooking & 4.19 & 4.22 & 3.70 & 4.16 & 1.147 \\
Stickiness after cooking & 3.99 & 4.03 & 3.70 & 3.93 & 1.155 \\
Long lasting of the softness & 3.86 & 3.90 & 3.80 & 3.77 & 1.027 \\
Grain size after cooking & 3.73 & 3.75 & 3.20 & 3.74 & 1.188 \\
Fluffy (Swelling) rice after cooking & 3.92 & 3.92 & 3.50 & 3.98 & 0.441 \\
Uniformity of quality after cooking & 3.96 & 3.96 & 3.60 & 3.98 & 0.380 \\
\hline Remarks: Score 1-1.8=unimportant; 1.81-2.6=somewhat important; 2.61-3.4=quite important \\
3.41-4.2 very important; and 4.21-5.0=extremely important. Where: * significant at 99\% CI; \\
**=significant at 95\% CI; ***=significant at 90\% CI \\
\hline
\end{tabular}

Table 10 Average score of important factors of cooking quality of rice those consumers emphasized classified by rice-type purchased group 


\begin{tabular}{lccccc}
\hline Cooking and eating quality & $\begin{array}{c}<\mathbf{2 6} \text { year- } \\
\text { old }\end{array}$ & $\begin{array}{c}\mathbf{2 6 - 3 5} \\
\text { year-old }\end{array}$ & $\begin{array}{c}\mathbf{3 6 - 5 5} \\
\text { year-old }\end{array}$ & $\begin{array}{c}>\text { 55 } \\
\text { year-old }\end{array}$ & F-test \\
\hline Taste & 4.40 & 4.36 & 4.41 & 4.46 & 0.137 \\
Fragrance & 4.10 & 4.08 & 4.09 & 4.08 & 0.271 \\
Softness after cooking & 4.27 & 4.14 & 4.13 & 4.46 & 0.964 \\
Stickiness after cooking & 4.00 & 3.93 & 3.89 & 4.05 & 0.467 \\
Long lasting of the softness & 3.89 & 3.81 & 3.98 & 3.83 & 0.453 \\
Grain size after cooking & 3.71 & 3.66 & 3.75 & 4.08 & 0.525 \\
Fluffy (Swelling) rice after cooking & 3.91 & 3.82 & 3.98 & 4.08 & 1.352 \\
Uniformity of quality after cooking & 3.93 & 3.99 & 4.09 & 4.00 & 0.498 \\
\hline
\end{tabular}

Remarks: Score 1-1.8=unimportant ; 1.81-2.6=somewhat important; $2.61-3.4=$ quite important 3.414.2 very important; and $4.21-5.0=$ extremely important

Table 11 Average score of important factors of cooking quality of rice those consumers emphasized classified by age group

The empirical results from Table 12 showed that the most important psychology factors rated by all rice consumers in Chengdu is self-fulfilment followed by self-respect, fun and enjoyment of life, respectively. The average importance score of the psychological factor on fun and enjoyment of life was statistically differed among the respondents whereas respondents purchased Thai rice placed more important than those respondents purchased Chinese rice only (Table 12).

\begin{tabular}{lccccc}
\hline Psychological factors & $\begin{array}{c}\text { Total } \\
\text { sample }\end{array}$ & $\begin{array}{c}\text { Buying Chinese } \\
\text { rice only }\end{array}$ & $\begin{array}{c}\text { Buying Thai } \\
\text { rice only }\end{array}$ & T-stat & Sig. \\
\hline Self-fulfilment & 4.20 & 4.25 & 4.10 & 0.70 & 0.24 \\
Being well respected & 3.82 & 3.81 & 3.85 & 0.39 & 0.35 \\
Fun and enjoyment of life * & 4.14 & 4.09 & 4.24 & 1.44 & 0.08 \\
Self-respect & 4.15 & 4.15 & 4.13 & 0.09 & 0.46 \\
\hline
\end{tabular}

Remarks: Score 1-1.8= unimportant; 1.81-2.6=somewhat important; $2.61-3.4=$ quite important 3.41-4.2 very important; and $4.21-5.0=$ extremely important. * significant at $90 \% \mathrm{CI}$

Table 12 Average score of psychological factors that consumers emphasized classified by rice-type purchased group

\section{Effects of rice attributes on price of Thai HomMali rice (Hedonic model)}

After testing for multicollinearity among all attributes and functional form of the model, the best model is in the linear form. The Least Squares (LS) has been used to analyze the relationship between the rice price and its attributes. It is hypothesized that rice price depends upon two main characteristics. The first one is physical characteristic of rice kernel which is visible from the appearance and rice package which included color of rice kernels in terms of white and transparent (COLOR), percentage of broken rice (PERCENTBR), length of rice kernels (LGRAIN), new crop rice (NEWRICE), rice standard (RSTANDARD), and brand of the rice (BRAND). The second is chemical characteristics which affect the cooking and eating quality. These can be characterized by softness after cooking (COOKSOFT), fragrance of rice after cooking (AROMA), and rice taste flavor (TASTE)

The estimated results found that the implicit price of the rice attributes (or characteristics) in China is affected by both physical and chemical characteristics. All these characteristics are statistically significant except the color of rice kernels (COLOR). Chengdu rice consumers are willing to pay premiums for better rice attributes and it seems to be that Chengdu rice consumers concern and value more on cooking and eating quality (AROMA) than physical characteristic (BRAND) (Table 13). These results were contrast with the study of Kaosa-ard and Juliano (1991), Kawamura (1999), Untong and Kasosa-ard (2010) and Sirisupluxana and Bunyasiri (2014) found that a consumer pay more based on physical attributes. 


\begin{tabular}{|c|c|c|}
\hline Items & Estimated Coefficient & T-stat \\
\hline \multicolumn{3}{|l|}{ Dependent variable: price of rice (RMB/kg.) } \\
\hline Constant term & 3.7167 & 2.4781 \\
\hline Color of rice kernels (COLOR) & $0.0607 \mathrm{~ns}$ & 1.3532 \\
\hline Percentage of broken rice (PERCENTBR) & $-0.3739^{\star \star \star x}$ & -2.3025 \\
\hline Length (long) of rice kernels (LGRAIN) & $0.4274^{\text {** }}$ & 2.0703 \\
\hline New crop rice (NEWRICE) & $0.4546^{* \star *}$ & 3.1592 \\
\hline Rice standard (RSTANDARD) & $0.4472^{*}$ & 1.9265 \\
\hline Brand image (BRAND) & $0.8912^{\star *}$ & 2.0805 \\
\hline Softness after cooking (COOKSOFT) & $0.7826^{\star *}$ & 2.2365 \\
\hline Rice taste (TASTE) & $0.4119^{*}$ & 1.8958 \\
\hline Fragrance of rice after cooking (AROMA) & $0.9165^{\star}$ & 1.6955 \\
\hline $\mathrm{R}^{2}$ & \multicolumn{2}{|l|}{0.7722} \\
\hline Adjusted $R^{2}$ & \multicolumn{2}{|l|}{0.7503} \\
\hline Durbin Watson (DW) & \multicolumn{2}{|l|}{1.5162} \\
\hline Number of samples & \multicolumn{2}{|l|}{104} \\
\hline \multicolumn{3}{|c|}{$\begin{array}{l}\text { Remarks: }{ }^{*}=\text { significant at } 99 \% \mathrm{CI} ;{ }^{* *}=\text { significant at } 95 \% \mathrm{CI} ;{ }^{* * *}=\text { significant at } 90 \% \mathrm{CI} \\
\text { Note: The reduction in sample size was due to missing data of the price of rice. }\end{array}$} \\
\hline
\end{tabular}

Table 13 Estimated coefficients or implicit price of hedonic price regression

\section{Summary and recommendation}

The study found that rice consumers in Chengdu always purchase rice in the modern trade retailers, supermarket in the department stores, and convenient stores and often buy Chinese rice (Tongbei rice). The important factor in deciding to buy rice is quality of rice (fragrant and softness of rice). The main reason for buying Thai rice is the taste of Thai rice. It is also found that those Thai rice buyers comparing with those buying Chinese rice are having comparatively high income and education, and having higher degree of joyful lifestyle, especially, for those younger and labor-productive age group between 26 and 35 years old. Thus, Thai rice target group in Sichuan Province would be young consumers and consumers with more income and more year of education.

The study on the hedonics price analysis found that both physical characteristics and chemical characteristics significantly influence the rice price. The physical characteristics that will increase the price of rice are less percentage of broken rice, longer length of rice kernels, and newer crop of rice, higher rice standard, and higher-end brand of rice. Whereas the chemical characteristics (cooking and eating quality) have the positive impact on rice price are better softness of rice after cooking, more taste flavor and more aroma. In addition, fragrance or aroma has more impact on rice price followed by rice brand image. Thus, to enhance the Thai rice market in Chengdu, Thai rice breeders have to keep the consistency of fragrance, taste and softness of HomMali rice which are the major factors that the Chinese consumers need, and Thai rice traders have to produce packaged rice with brand image according to the taste of Chengdu consumers. In addition, Thai government and traders should promote and create the identity and difference of HomMali rice from Chinese rice by providing all information of Thai HomMali rice to consumers, particularly the unique quality and this information should be summarized in Chinese and printed on the rice package. Furthermore, Thai traders should build consumers' trust on the uniformity of taste and fragrance of HomMali rice and should be in cooperation with the modern trade retailers to provide consumer with actual experience in eating and testing of Thai HomMali rice to enhance Thai rice market share in Sichuan Province.

\section{Further study}

The limitation of this study is that the study was applied only on certain city in Sichuan. The further study should be extended to consumers in surrounding cities of Chengdu in order to get more information about the consumer perspectives on attributes of Thai rice and Chinese consumer preference in Sichuan Province.

\section{References}

Adesina, A.A. and J. Baidu-Forson, 1995. Farmers' Perceptions and Adoption of New Agricultural Technology: Evidence from Analysis in Burkina Faso and Guinea West Africa. Agricultural Economics, 13: 1-9. 
Breidert, C., 2006.Estimation of Willingness-to-pay: Theory, Measurement, Application. Wiesbaden: Deutscher Universitäts-Verlag.

Dalton, Timothy J., 2004. A Household Hedonic Model of Rice Traits: Economic Values from Farmers in West Africa. Agricultural Economics, Volume 31, Issue 2-3, 149-159.

Kaosa-ard, M. and B.O. Juliano, 1991. Assessing Rice Quality Characteristics and Prices in Selected International Markets. Rice Grain Marketing and Quality Issues, International Rice Research Institutes, Philippines, 23-25.

Kawamura, T., 1999.Hedonic Price Analysis and its Application to Package Design: Packaged Cooked Rice in Japan, World Food and Agribusiness Congress, 13-14.

Kha, Pham Nguyen Hoang, and VyHoai Trinh. "Issues Surrounding the Rice Price of Thailand from 2003 to 2013." (2017).

Ladd, G.W., and V. Suvannunt, 1976. A Model of consumer Goods Characteristics. American Agricultural Economics Association, 58: 504-10.

Lancaster, K., 1966. A New Approach to Consumer Theory. Journal of Political Economics, 74: 132-157.

Musa, M., Othman, N., \& Fatah, F. A. (2011). Determinants of consumers purchasing behavior for rice in Malaysia. American International Journal of Contemporary Research, 1(3), 159-167.

Rosen, S., 1974. Hedonic Prices and Implicit Markets: Product Differentiation in Pure Competition. Journal of Political Economy, 82:34-55.

Sirisupluxana, P. and I. N. Bunyasiri, 2014.Demand for Thai Rice Project, TDRI (in Thai).

Unnevehr, Laurian J., 1986. Consumer demand for rice grain quality and returns to research for quality Improvement in Southeast Asia. American Agricultural Economics Association.

Untong, A. D. and M. Kaosa-ard, 2010. Import Demand for Thai Rice and Factors Determining price and rice in Modern Trading Market in China. Journal of Applied Economics, Volume 17, No. 2 (in Thai)

USDA, 2014. Economic Research Service using Foreign Agricultural Service, Production, Supply, and Distribution database.

Waugh, Frederick V., 1929.Quality as a Determinant of Vegetable Prices. New York: Columbia University Press. 